\title{
ЕФЕКТИВНІСТЬ СХРЕЩУВАННЯ РОСІЙСЬКОЇ РИСИСТОЇ ПОРОДИ УКРАЇНСЬКОЇ ПОПУЛЯЦІЇ 3 ФРАНЦУЗЬКОЮ РИСИСТОЮ
}

\author{
Ткачова Ірина Володимирівна \\ доктор сільськогосподарських наук, ст. науковий співробітник \\ Інститут тваринництва НААН \\ ORCID: 0000-0002-4235-7257 \\ E-mail: i-tkachova@yandex.ru \\ Ткаченко Олександра Олександрівна \\ кандидат сільськогосподарських наук, ст. науковий співробітник \\ Інститут тваринництва НАAН \\ ORCID: 0000-0002- \\ E-mail: snegireva.aleksandra@mail.ru
}

\begin{abstract}
Для удосконалення російської рисистої породи як вітчизняної, так і російської популяцій традиційно використовується схрещування з вихідною - американською стандартбредною породою, що походить від чистокровної верхової і $\epsilon$ найжвавішою з усіх рисистих порід. Альтернативою поглинального схрещування рисистих коней вітчизняної селекції $з$ американською стандартбредною є помірне використання плідників фрранцузької рисистої породи, яке останнім десятиріччям набуває у селекційній роботі все більшого масштабу. Популярність плідників фрранцузької рисистої породи у вітчизняних заводчиків останніми роками пов'язана з їх успіхом на світових іподромах, а також обумовлена походженням їх від видатних плідників американської стандартбредної породи і належністю до найпрогресивніших ліній та гілок. Таким чином, використовуючи їх, селекціонери компенсують відсутність висококласних плідників американської стандартбредної породи. Встановлено, що використання генофонду франиузької рисистої породи для схрещування дає можливість поліпшити селекиійні ознаки коней російської рисистої породи вітчизняної популяції і зменшити інбредну депресію в умовах роботи з обмеженим генофондом породи. Експериментально доведено позитивний вплив схрещування російської рисистої породи з фрранцузькою рисистою на удосконалення характеристик жвавості коней. В усіх вивчених групах молодняк, помісний за фрранцузькою рисистою породою переважав чистопородних ровесників обох рисистих порід за жвавістю на 1600 м. Коні, одержані від жеребців французької рисистої породи виявилися жвавішими за ровесників, одержаних від жеребців американської стандартбредної породи: у віці двох років - на 0,5 c, трьох років - на 1,2 с, чотирьох років - на 1,1 с. При цьому у потомстві жеребців американської стандартбредної породи виявлено більше коней класу жвавості 2.10 хв і жвавіше - на 7,2 \%, класу жвавості 2.05 хв і жвавіше - на 8,9 \%. Жеребці-плідники американської стандартбредної породи в середньому поступалися жеребиям фрранцузької селекції за жвавістю на 1600 м на 2,3 c.
\end{abstract}

Ключові слова: коні, українська популячія, російська рисиста, фрранцузька рисиста, схрещування, жвавість

DOI: https://doi.org/10.32845/bsnau.Ivst.2019.1-2.14

У світі відомі чотири оригінальні породи рисистих коней, що відрізняються між собою методами створення, роботоздатністю, екстер'єрними характеристиками: орловська рисиста, американська стандартбредна, французька рисиста та скандинавський холоднокровний рисак (до якої відносять три різновиди - норвезьких, шведських та фінських коней) [1].

Російська рисиста порода має певну популярність в Україні походить від простого відтворювального схрещування орловської та американської порід [2]. Російська рисиста порода виведена шляхом схрещування кращих орловських кобил з американськими жеребцями, яке практикували з 90$\mathrm{x}$ років XIX ст. [3]. Схрещування започаткували як промислове, для швидкого поліпшення жвавості коней першої генерації, з часом накопичувалися помісі з більш високою кровністю за американською породою. Помісних коней схрещували між собою, а також використовували зворотне схрещування їх з орловськими плідниками і в 1949 році було затверджено нову породу. Наразі коней російської рисистої породи розводять переважно в Росії та Україні. Зважаючи на визначені відмінності за фенотипом та генотипом двох популяцій, в Україні проводиться робота з апробації української рисистої породної групи на базі масиву рисистих коней [4].

Вісник Сумського національного аграрного університету Серія «Тваринництво», випуск 1-2 (36-37), 2019
Враховуючи недостатність якісних жеребцівплідників російської рисистої породи вітчизняної селекції, а також досвід країн з розвиненим кіннозаводством, де широко практикується обмін та закупівля кращого за показниками роботоздатності племінного матеріалу для збагачення генофонду порід та підвищення якості основних селекційних ознак, селекціонери прагнуть використовувати племінний матеріал стандартбредних рисаків з країн Західної Європи та Америки. Ефективність схрещувань російської рисистої та інших рисистих порід з американською стандартбредною широко висвітлено у наукових працях вітчизняних і зарубіжних дослідників [2, 5-7]. Разом 3 тим, захоплення схрещуванням зі стандартбредним рисаком у російських кінних заводах призвело до того, що останнім часом родоводи російських рисаків занадто насичені кличками стандартбредних плідників, часто невисокої якості, що негативно впливає на призову роботоздатність, погіршує запряжний тип, екстер'єрні та продуктивні якості коней [8].

Альтернативою поглинання російської рисистої породи $з$ американською стандартбредною $є$ помірне схещування з французькою рисистою, яке останнім десятиріччям набуває у селекційній роботі все більшого масштабу. Досвід схрещування з французькими рисистими плідниками мав давній, але епізодичний характер [9]. 
у походженні французьких рисаків спостерігається багато спільного з методами селекції орловських рисаків: накопичення у дальніх рядах предків видатних представників, помірний інбридинг на кращих представників дозволили отримати жвавого і консолідованого рисака [10]. Французьку рисисту породу спочатку створювали як породу комбінованого використання в запряжці та під сідлом у XIX-XX ст. у провінції Нормандія шляхом схрещування місцевих грубуватих масивних коней з арабською, а згодом - з чистокровною верховою і норфолкською породами. Пізніше в селекційній роботі використовували також орловських та американських рисаків. Добір і тренінг коней передбачав розвиток поряд зі жвавістю і витривалості, бо дистанція встановлювалась - 4-6 км. Поєднання цих якостей закріплювали у нащадків і в результаті отримали рисистих коней, що вирізняються стаєрськими здібностями і є світовими рекордистами на довгі дистанції [11]. Коні цієї породи мають широке розповсюдження, французька популяція породи включає 650 жеребців-плідників та 17 тисяч племінних кобил. Щороку до 14 тисяч французьких рисаків змагаються на іподромах і приносять значний прибуток своїм власникам [7].

Висока жвавість на стаєрські дистанції у поєднанні 3 виразним запряжним типом, крупним калібром, правильним екстер'єром - ті якості, яких потребує вітчизняне рисисте кіннозаводство задля підвищення конкурентноздатності на зовнішньому ринку. Для цього в європейській практиці давно застосовують схрещування з французькою рисистою породою. Так, у рисистому кіннозаводстві Швеції та Італії використовується практика прилиття крові французької рисистої породи на рівні $1 / 4-1 / 8$ (коні видатної жвавості Varenne, Copiad, Ina Scot, Mr Lavec). Окрім підвищення жвавості коней, цей метод є одним із засобів запобігання інбредній депресії у малочисельних замкнутих популяціях [12].

Проведений аналіз родоводів рисистих коней вітчизняної популяції показав, що вперше ввідне схрещування російського рисака з французьким на початку 1960-х років було обмежене вузьким використанням двох посередніх за жвавістю французьких жеребців: Халебрана 1.19,6 хв.с (Квіпрокво - Отті Порт) та Жолі Гамена 1.21,0 хв.с (Ма Гамен - Абзац). Від цих жеребців було отримано дуже мало нащадків, що не дало можливості вірогідно оцінити їх, хоча кілька їх нащадків увійшло до жвавого класу 2.10 хв.с і жвавіше: Карабах 2.09,5 хв.с, Купаж 2.10,0 хв.с, Зажимка 2.08,5 хв.с. Більш широкого масштабу схрещування набуло з 1965 року, коли були імпортовані з Франції жеребці: Окапі'С 1.16,6 хв.с (Фе Фоллє X - Жант'ян V) та Н'Ас Ер Аш 1.20, хв.с (Арісто - Граціелло Аш). Від цих жеребців було отримано і випробувано 82 нащадки. Окапі'С був жвавішим трирічним рисаком Франції тих часів і дав кілька ставок лошат у Дібрівському кінному заводі [13].

Порівняння жвавості отриманих помісей з матерями показало, що нащадки Окапі'С на дистанцію 1600 м поступалися своїм матерям за жвавістю: в два роки - на 3,2 с, в 3 роки - на 2,8 с, в 4 роки і старше - на 3,3 с. Потомки французьких жеребців в середньому були жвавіші за своїх чистопорідних ровесників (російської рисистої породи), але поступалися потомству стандартбредних жеребців (табл. 1).

За попередніми дослідженнями - основна особливість франко-російських помісей - відставання дворічок за жвавісною скоростиглістю та перевага над російськими ровесниками в старшому віці [14]. Таким чином, Окапі'С та Н'Ас Ер Аш стійко передавали потомству жвавісну пізньостиглість, яка, одначе, компенсувалася високими дистанційними якостями

Таблиця 1

Порівняльна характеристика молодняку коней рисистих порід, одержаних від жеребців різних порід

\begin{tabular}{|c|c|c|c|c|c|c|}
\hline \multirow[b]{2}{*}{ Групи нащадків } & \multicolumn{2}{|c|}{ 2-х років } & \multicolumn{2}{|c|}{ 3-х років } & \multicolumn{2}{|c|}{ 4-х років } \\
\hline & $\begin{array}{c}\text { середня } \\
\text { жвавість, хв.с }\end{array}$ & $\begin{array}{c}\text { коней класу } \\
2.20(\%)\end{array}$ & $\begin{array}{c}\text { середня } \\
\text { жвавість, Хв.с }\end{array}$ & $\begin{array}{c}\text { коней класу } \\
2.15(\%)\end{array}$ & $\begin{array}{c}\text { середня } \\
\text { жвавість, Хв.с }\end{array}$ & $\begin{array}{c}\text { коней класу } \\
2.10(\%)\end{array}$ \\
\hline $\begin{array}{l}\text { Потомство чистопорідних російських } \\
\text { рисистих жеребців }(\mathrm{n}=572)\end{array}$ & $\begin{array}{l}2.42,8 \\
\pm 0,08\end{array}$ & 0,8 & $\begin{array}{l}2.27,3 \\
\pm 0,24\end{array}$ & 5,8 & $\begin{array}{l}2.24,3 \\
\pm 0,14\end{array}$ & 2,5 \\
\hline $\begin{array}{l}\text { Потомство французьких рисистих } \\
\text { жеребців (n=82) * }\end{array}$ & $\begin{array}{l}2.42,3 \\
\pm 0,17\end{array}$ & - & $\begin{array}{l}2.26,3 \\
\pm 0,15\end{array}$ & 5,8 & $\begin{array}{l}2.21,1 \\
\pm 0,07\end{array}$ & 12,3 \\
\hline $\begin{array}{l}\text { Потомство стандартбредних жеребців } \\
(\mathrm{n}=439)\end{array}$ & $\begin{array}{l}2.37,5 \\
\pm 0.09\end{array}$ & 1,6 & $\begin{array}{l}2.22,3 \\
\pm 0.11\end{array}$ & 18,5 & $\begin{array}{l}2.16,3 \\
\pm 0.19\end{array}$ & 21,1 \\
\hline
\end{tabular}

Примітка: * - за даними В.О. Ліппінга [10]

Серед отриманих від Окапі'С нащадків - п'ятеро класу 2.05 хв.с і жвавіше, причому троє - перевершили батька за жвавістю. В Дібрівському кінному заводі був отриманий один з кращих його синів - Гладіолус - рекордист 1973 року, який показав високу жвавість - 2.01,4 хв.с. на 1600 м і 3.15,5 хв.с на 2400 м, дав трьох нащадків класу 2.05 хв.с і жвавіше. Його донька Гербера показала кращу за батька жвавість на дистанцію 2400 м - 3.10,5 хв.с. Ще один син Окапі'С - Командор показав жвавість 2.01,8 хв.с та дав кілька ставок нащадків з середньою жвавістю на 1600 м: 2-х років - 2.42,3 хв.с; 3-х років - 2.18,1 хв.с; 4-х років - 2.11,4 хв.с, серед яких троє - класу 2.05 хв.с і жвавіше, близько половини нащадків ввійшли до відтворювального складу. Син Командора - Вікінг встановив абсолютный рекорд на 2400 м - 3.00,4 хв.с. В сучасному маточному складі російської рисистої породи української частини популяції викорис- товуються чотири кобили, що походять від Окапі'С.

3 уособленням вітчизняної частини популяції російської рисистої породи ситуація з жеребцями-плідниками значно погіршилася. 3 метою швидкого отримання жвавих коней безконтрольно використовувались стандартбредні жеребці, часто сумнівної якості, що значно погіршувало племінні якості породи. На цьому фоні з 1994 по 2000 роки в Дібрівському кінному заводі досить вдало використовувався французький рисистий жеребець Мінден 1.17 хв.с (Брутус Люциус - Маде) лінії Фанданго - переможець 14 призів на Венсенському іподромі, і виграш якого склав - 852 тис. франків. Цей некрупний але глибокий жеребець з яскраво вираженим запряжним типом дав більше 80 нащадків, з них $24(29,6 \%)$ - класу 2.10 і жвавіше, $5(6,2 \%)$ - класу 2.05 і жвавіше [15].

Серед кращих за жвавістю нащадків Міндена насту- 
пні: коб. Москва (рекордистка СНГ на дистанції 2400 і 3200 м; рекордна жвавість на 1600 м - 2.03,5 хв.с, на 2400 м $3.09,4$ хв.с; на 3200 м - 4.16,3 хв.с; на 4800 м - 6.55,6 хв.с; переможці і призери традиційних призів Вілла 2.05 хв.с, Воля 2.09,3 хв.С, Герміт 2.02,5 хв.С, Граматика 2.06,9 хв.С, Гримуча 2.09,8 хв.с, Гряда 2.06,3 хв.с, Зумер 2.09,1 хв.с, Кадмєя 2.08 хв.с, Камельок 2.07,9 хв.с, Кармен 2.07,7 хв.с, Клема 2.08,4 хв.с, Мальва 2.10 хв.с, Мангуш 3.12,6 хв.с (на 2400 м), Римлянка 2.04,1 хв.с (на 1600 м); 3.14,3 хв.с (на 2400 м). Сини Міндена - Камельок і Герміт та 12 дочок Міндена, зокрема - вищезгадані Вілла, Воля, Клема, Москва, Римлянка також увійшли до відтворювального складу. На сьогодні близько 3 \% відтворювального складу кобил російської рисистої породи вітчизняної частини популяції походить від Міндена.

На сьогодні рекорди рисаків в США та Західній Європі набагато вищі за українських та російських [16]. Головні міжнародні призи розігруються зі жвавістю порядку 1.55-1.56 на 1600 м, в той час, як рисаки вітчизняної селекції не можуть подолати абсолютний рекорд Властного - 1.58,7, встановлений у 1975 році. Останнім часом французькі рисаки досягли значних успіхів, успішно конкурують зі стандартбредними рисаками, мають рекорди на рівні 1.55-1.57, при цьому поєднують високий біговий клас з ростом та виразним запряжним типом, хоча і залишаються пізньостиглими і проявляють рекордну жвавість у віці 5-7 років [17]. Враховуючи поглинання російського рисака стандартбредним, що призвело до втрати оригінальності типу, успішність французького рисака, який зберігає запряжний тип та дистанційність, позитивний досвід франко-російських схрещувань (наявність серед нащадків рекордистів та коней високого бігового класу), перспектива отримання трипородних помісей, помірне використання французьких плідників - один 3 перспективних напрямків удосконалення вітчизняної частини популяції російської рисистої породи.

В 2002-2004 році було закуплено спермопродукцію французької селекції (кінний завод «France Trot») від жеребців-плідників французької селекції: Б'єсоло 1.16 хв.с (в перерахунку на 1600 м - 2.01,6) і Дахір де Прєлон 1.14 хв.с (на 1600 м - 1.58,4), Карп Д'ьєм 1.14 хв.с (1.58,4), Імо Жосселін 1.13 хв.с (1.56,8). Зазначені жеребці відносилися до кращих плідників Франції, були переможцями престижних призів, оцінені за якістю потомства - від них походить значна кількість висококласних рисаків.

Спермопродукцію імпортованих жеребців було розподілено по трьох кінних заводах та чотирьох провідних племінних репродукторах (табл. 2), маточний склад яких найбільше відповідав високому класу жвавості жеребцівплідників фрранцузької селекції.

\section{Розподіл спермопродукції жеребців-плідників французької селекції}

Таблиця 2 у суб'єктах племінної справи України

\begin{tabular}{|l|c|}
\hline \multicolumn{1}{|c|}{$\begin{array}{c}\text { Суб'єкт племінної справи } \\
\text { (клички жеребців) }\end{array}$} & Кількість спермодоз \\
\hline Запорізький кінний завод № 86 (Дахір де Прєлон, Карп Д'єм, Б'єсоло) & 18 \\
\hline Дібрівський кінний завод № 62 (Дахір де Прєлон, Карп Д'єм, Б'єсоло, Імо Жосселін) & 17 \\
\hline Мирогощанський аграрний колледж (Дахір де Прєлон) & 3 \\
\hline ТОВ «ЕЛ-ТУР» (Дахір де Прєлон, Карп Д'єм, Б'єсоло) & 15 \\
\hline ПСП «Комишанське» (Карп Д'єм, Б'єсоло) & 9 \\
\hline Кінний завод «Шахтар» (Карп Д'єм, Б'єсоло) & 6 \\
\hline ГО «Асоціація рисистого конярства» (Дахір де Прєлон, Б'єсоло) & 6 \\
\hline Всього: & 5 \\
\hline
\end{tabular}

у 2006 році на Київському іподромі було випробувано першу ставку дворічного помісного молодняку, з яких 3 голови - від Б'єсоло, 2 - від Імо Жоселін та 1 - від Карп Д'єм. Також було продовжено випробування жеребця старшого віку, одержаного від французького рисистого жеребця Міндена. У наступних роках кількість помісного ти чистопорідного фрранцузького рисистого молодняку збільшувалась (табл. 3).

Таблиця 3

Кількість молодняку різних генетичних груп, випробуваного на Київському іподромі (2006-2016 рр.)

\begin{tabular}{|c|c|c|c|c|c|c|c|c|c|c|c|c|c|c|c|c|c|c|c|c|c|c|c|c|c|}
\hline \multirow[t]{3}{*}{ Роки } & \multicolumn{5}{|c|}{$\begin{array}{l}\text { Помісні (одержані від плідників } \\
\text { французької рисистої породи) }\end{array}$} & \multicolumn{5}{|c|}{$\begin{array}{c}\text { Чистопородні (французької } \\
\text { рисистої породи) }\end{array}$} & \multicolumn{5}{|c|}{$\begin{array}{c}\text { Помісні (одержані від плідників } \\
\text { американської стандартбредної } \\
\text { породи) }\end{array}$} & \multicolumn{5}{|c|}{$\begin{array}{l}\text { Чистопородні (американської } \\
\text { стандартбредної породи) }\end{array}$} & \multicolumn{5}{|c|}{$\begin{array}{c}\text { Помісні (одержані від } \\
\text { схрещування коней } \\
\text { американської стандартбредноі } \\
\text { та французької рисистої порід) }\end{array}$} \\
\hline & \multirow{2}{*}{$\mathrm{n}$} & \multicolumn{4}{|c|}{ вікові групи, років } & & \multicolumn{4}{|c|}{ вікові групи, років } & \multirow[b]{2}{*}{. } & \multicolumn{4}{|c|}{ вікові групи, років } & \multirow[b]{2}{*}{$\mathrm{n}$} & \multicolumn{4}{|c|}{ вікові групи, років } & \multirow[b]{2}{*}{$\mathrm{n}$} & \multicolumn{4}{|c|}{ вікові групи, років } \\
\hline & & 2 & 3 & 4 & 5 іст. & & 2 & 3 & 4 & 5 іст. & & 2 & 3 & 4 & $5 \mathrm{ict}$. & & 2 & 3 & 4 & 5 іст. & & \begin{tabular}{|l|}
2 \\
\end{tabular} & 3 & 4 & 5 іст. \\
\hline 2006 & 7 & 6 & - & - & 1 & - & - & - & - & - & 40 & 11 & 7 & 13 & 9 & 1 & 1 & - & - & - & - & - & - & - & - \\
\hline 2007 & 12 & 5 & 6 & - & 1 & 3 & 3 & 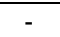 & - & - & 34 & 7 & 12 & 3 & 12 & 1 & - & 1 & - & - & - & - & - & - & - \\
\hline 2008 & 9 & - & 5 & 4 & - & 3 & 1 & 2 & - & - & 33 & 12 & 7 & 7 & 7 & 1 & 1 & - & 1 & - & 1 & 1 & - & - & - \\
\hline 2009 & 5 & 2 & - & 3 & - & 8 & 4 & 1 & 2 & - & 43 & 18 & 12 & 5 & 8 & -1 & - & - & - & - & 1 & - & 1 & - & - \\
\hline 2010 & 14 & 10 & 2 & 2 & - & 12 & 6 & 3 & 2 & 1 & 24 & 3 & 12 & 4 & 5 & 2 & 2 & - & - & - & 2 & 1 & - & 1 & - \\
\hline 2011 & 13 & 3 & 9 & 1 & - & 28 & - & 11 & 14 & 3 & 18 & 4 & 2 & 6 & 6 & 3 & - & 2 & - & 1 & 2 & 1 & 1 & - & - \\
\hline 2012 & 12 & 2 & 6 & 4 & - & 34 & 4 & 8 & 6 & 16 & 16 & 4 & 4 & 1 & 7 & 2 & - & - & 1 & 1 & 4 & 4 & - & - & - \\
\hline 2013 & 16 & 9 & 4 & 3 & - & 35 & 9 & 3 & 6 & 17 & 14 & 2 & 5 & 3 & 4 & - & - & - & - & - & 4 & 1 & 3 & - & - \\
\hline 2014 & 15 & 5 & 8 & 2 & - & 16 & 4 & 8 & 3 & 1 & 11 & 4 & 3 & 2 & 2 & - & - & - & - & - & 4 & 1 & 1 & 2 & - \\
\hline 2015 & 14 & 3 & 5 & 6 & - & 41 & 12 & 4 & 7 & 18 & 4 & 2 & 2 & - & - & - & - & - & - & - & 5 & 1 & 2 & 1 & 1 \\
\hline 2016 & 10 & 5 & 3 & 2 & - & 39 & 8 & 10 & 3 & 18 & 4 & 1 & 2 & 1 & - & 2 & 2 & - & - & - & 15 & 9 & 3 & 2 & 1 \\
\hline Всього: & & & 127 & & & & & 219 & & & & & 241 & & & & & 12 & & & & & 38 & & \\
\hline
\end{tabular}

32004 року до України були завезені перші кобили | та жеребці-плідники французької рисистої породи, які у 2005

Вісник Сумського національного аграрного університету 
році дали першу ставку лошат французької рисистої породи, що визнаються Племінною книгою Франції. На сьогодні основні суб'єкти з розведення цієї породи - ПР «Рода» Київської та ПСП «Комишанське» Сумської областей.

Аналіз призової роботоздатності коней різних вікових груп, одержаних від плідників французької рисистої породи, що випробовувались на Київському іподромі останнім десятиріччям показав (табл. 4), що в усіх вивчених групах молодняк, помісний за французькою рисистою породою переважав чистопородних ровесників обох рисистих порід за жвавістю на 1600 м.

Порівняльний аналіз призової роботоздатності коней на дистанцію 1600 м,

Таблиця 4 одержаних від жеребців рисистих порід

\begin{tabular}{|c|c|c|c|c|c|c|c|}
\hline \multirow{3}{*}{ Рік } & \multirow{3}{*}{ Вік, років } & \multicolumn{6}{|c|}{ Групи коней } \\
\hline & & \multicolumn{2}{|c|}{$\begin{array}{c}\text { чистопородні російської рисистої } \\
\text { породи }\end{array}$} & \multicolumn{2}{|c|}{$\begin{array}{c}\text { чистопородні франццуької } \\
\text { рисистої породи }\end{array}$} & \multicolumn{2}{|c|}{$\begin{array}{c}\text { помісні (потомство жеребців } \\
\text { французької рисистої породи) }\end{array}$} \\
\hline & & $\mathrm{n}$ & жвавість, хв.С & $\mathrm{n}$ & жвавість, хв.С & $n$ & жвавість, хв.С \\
\hline \multirow{4}{*}{2010} & 2 & 58 & $2.27,7 \pm 0,19$ & 6 & $2.20,2 \pm 0,26$ & 10 & $2.25,2 \pm 0,31$ \\
\hline & 3 & 50 & $2.16,3 \pm 0,54$ & 3 & $2.10,2 \pm 0,40$ & 2 & $2.14,8 \pm 0,63$ \\
\hline & 4 & 41 & $2.06,9 \pm 0,38$ & 2 & $2.04,4 \pm 0,32$ & 2 & $2.06,9 \pm 0,15$ \\
\hline & Ст. вік & 28 & $2.04,9 \pm 0,29$ & 1 & $2.06,2$ & - & - \\
\hline \multirow{4}{*}{2011} & 2 & 63 & $2.30,1 \pm 0,21$ & - & - & 3 & $2.27,2 \pm 0,55$ \\
\hline & 3 & 61 & $2.15,5 \pm 0,41$ & 11 & $2.13,7 \pm 0,23$ & 9 & $2.15,1 \pm 0,22$ \\
\hline & 4 & 30 & $2.09,7 \pm 0,20$ & 14 & $2.07,9 \pm 0,10$ & 1 & $2.06,7$ \\
\hline & Ст. вік & 32 & $2.05,7 \pm 0,32$ & 3 & $2.06,4 \pm 0,09$ & - & - \\
\hline \multirow{4}{*}{2012} & 2 & 70 & $2.30,5 \pm 0,17$ & 4 & $2.26,6 \pm 0,07$ & 2 & $2.16,3 \pm 0,16$ \\
\hline & 3 & 52 & $2.14,6 \pm 0,28$ & 8 & $2.11,8 \pm 0,16$ & 6 & $2.12,9 \pm 0,34$ \\
\hline & 4 & 34 & $2.08,3 \pm 0,25$ & 6 & $2.07,0 \pm 0,05$ & 4 & $2.06,6 \pm 0,07$ \\
\hline & Ст. Вік & 20 & $2.05,1 \pm 0,17$ & 16 & $2.05,3 \pm 0,07$ & - & - \\
\hline \multirow{4}{*}{2013} & 2 & 58 & $2.25,8 \pm 0,32$ & 9 & $2.29,8 \pm 0,33$ & 9 & $2.25,3 \pm 0,14$ \\
\hline & 3 & 61 & $2.15,2 \pm 0,27$ & 3 & $2.16,4 \pm 0,19$ & 4 & $2.09,3 \pm 0,25$ \\
\hline & 4 & 32 & $2.10,4 \pm 0,34$ & 6 & $2.07,0 \pm 0,09$ & 3 & $2.07,1 \pm 0,23$ \\
\hline & Ст. вік & 16 & $2.04,6 \pm 0,22$ & 17 & $2.05,9 \pm 0,51$ & - & - \\
\hline \multirow{4}{*}{2014} & 2 & 41 & $2.25,0 \pm 0,12$ & 4 & $2.26,1 \pm 0,24$ & 5 & $2.24,3 \pm 0,24$ \\
\hline & 3 & 42 & $2.12,7 \pm 0,95$ & 8 & $2.24,0 \pm 0,47$ & 8 & $2.10,6 \pm 0,14$ \\
\hline & 4 & 24 & $2.06,2 \pm 0,06$ & 3 & $2.07,3 \pm 0,62$ & 2 & $2.10,6 \pm 0,64$ \\
\hline & СТ. Вік & 4 & $2.04,8 \pm 0,15$ & 1 & $2.28,5$ & - & - \\
\hline \multirow{4}{*}{2015} & 2 & 46 & $2.25,8 \pm 0,17$ & 12 & $2.24,5 \pm 0,31$ & 3 & $2.15,0 \pm 0,15$ \\
\hline & 3 & 41 & $2.13,1 \pm 0,11$ & 4 & $2.17,4 \pm 0,41$ & 5 & $2.10,9 \pm 0,14$ \\
\hline & 4 & 30 & $2.08,2 \pm 0,09$ & 7 & $2.17,8 \pm 0,43$ & 6 & $2.07,0 \pm 0,86$ \\
\hline & Ст. вік & 4 & $2.02,4 \pm 0,05$ & 18 & $2.05,4 \pm 0,44$ & - & - \\
\hline \multirow{4}{*}{2016} & 2 & 40 & $2.30,5 \pm 0,15$ & 8 & $2.22,9 \pm 0,21$ & 5 & $2.20,0 \pm 0,27$ \\
\hline & 3 & 28 & $2.11,1 \pm 0,13$ & 10 & $2.12,5 \pm 0,15$ & 3 & $2.06,4 \pm 0,21$ \\
\hline & 4 & 18 & $2.08,6 \pm 0,12$ & 3 & $2.09,7 \pm 0,27$ & 2 & $2.04,1 \pm 0,15$ \\
\hline & СТ. вік & 8 & $2.00,9 \pm 0,05$ & 18 & $2.05,0 \pm 0,41$ & - & - \\
\hline \multirow{4}{*}{ В середньому: } & 2 & 1195 & $2.30,8 \pm 0,50$ & 43 & $2.25,0 \pm 0,14$ & 37 & $2.23,3 \pm 0,12$ \\
\hline & 3 & 1085 & $2.16,3 \pm 0,66$ & 47 & $2.15,2 \pm 0,13$ & 37 & $2.11,9 \pm 0,97$ \\
\hline & 4 & 763 & $2.10,3 \pm 0,27$ & 41 & $2.09,3 \pm 0,10$ & 20 & $2.05,0 \pm 0,71$ \\
\hline & СТ. вік & 502 & $2.06,6 \pm 0,49$ & 74 & $2.05,5 \pm 0,24$ & - & - \\
\hline
\end{tabular}

За середніми показниками жвавості за вивчений селекційний період (2010-2016 рр.) встановлено, що у віці двох років помісний молодняк переважав чистопородний (російської рисистої породи) на 7,5 c (Р>0,95), трьох років - на 4,4 с $(P<0,90)$, чотирьох років - на 4,7 с $(P>0,90)$. Ровесників французької рисистої породи помісні коні переважали у відповідні вікові періоди на 1,7 с, 3,6 с та 4,3 с.

Протягом дослідного періоду (2006-2016 рр.) у схрещуванні з російською рисистою породу було використано 12 жеребців-плідників фрранцузької рисистої породи. Ефективність їх використання наведено в таблиці 5. 
Ефективність використання плідників французької рисистої породи, допущених до схрещування з російською рисистою породою вітчизняної селекції (2006-2016рр.)

\begin{tabular}{|c|c|c|c|c|c|c|c|c|c|}
\hline \multirow{3}{*}{ Жеребці-плідники } & \multirow{3}{*}{$\begin{array}{l}\text { Жвавість, } \\
\text { на } 1600 \text { м, хв.с }\end{array}$} & \multirow{3}{*}{$\begin{array}{c}\text { Випробувано } \\
\text { потомства, } \\
\text { гол. }\end{array}$} & \multicolumn{4}{|c|}{$\begin{array}{c}\text { Виявлено коней } \\
\text { класу жвавості, хв.с: }\end{array}$} & \multicolumn{3}{|c|}{$\begin{array}{c}\text { Жвавість на дистанцію } 1600 \text { м у вікові } \\
\text { періоди, років: }\end{array}$} \\
\hline & & & \multicolumn{2}{|c|}{2.10} & \multicolumn{2}{|c|}{2.05} & \multirow{2}{*}{2} & \multirow{2}{*}{3} & \multirow{2}{*}{4} \\
\hline & & & $\mathrm{n}$ & $\%$ & $\mathrm{n}$ & $\%$ & & & \\
\hline Б'єсоло & $2.01,6$ & 7 & 4 & 57,1 & - & - & $\begin{array}{l}2.32,0 \\
\pm 0,31\end{array}$ & $\begin{array}{l}2.14,4 \\
\pm 0,18\end{array}$ & $\begin{array}{l}2.07,2 \\
\pm 0,07\end{array}$ \\
\hline Дахір де Прєлон & $1.58,4$ & 1 & - & - & - & - & $2.22,1$ & $2.19,8$ & - \\
\hline Карп Д'єм & $1.58,3$ & 9 & 4 & 44,4 & 1 & 11,1 & $\begin{array}{l}2.33,3 \\
\pm 0,28\end{array}$ & $\begin{array}{l}2.12,7 \\
\pm 0,15\end{array}$ & $\begin{array}{l}2.07,3 \\
\pm 0,22\end{array}$ \\
\hline Еліо Жосселін & H.B. & 1 & - & - & - & - & $2.19,8$ & $2.10,4$ & - \\
\hline Ідало & $1.58,4$ & 7 & 4 & 57,1 & - & - & $\begin{array}{l}2.18,8 \\
\pm 0,20\end{array}$ & $\begin{array}{l}2.09,1 \\
\pm 0,12\end{array}$ & $\begin{array}{l}2.07,5 \\
\pm 0,15\end{array}$ \\
\hline Ілліко Престо & $1.59,9$ & 1 & - & - & - & - & $2.27,9$ & $2.21,0$ & - \\
\hline Імо Жосселін & $1.56,8$ & 2 & - & - & - & - & $\begin{array}{l}2.28,5 \\
\pm 0,15\end{array}$ & $\begin{array}{l}2.15,2 \\
\pm 0,22\end{array}$ & $\begin{array}{l}2.12,4 \\
\pm 0,15\end{array}$ \\
\hline Ін Лав Віз Ю & $1.58,1$ & 2 & 1 & 50,0 & - & - & $2.21,8$ & $2.10,7$ & $2.08,8$ \\
\hline Інтерпід д’Авіль & $1.57,1$ & 7 & 2 & 28,6 & 1 & 14,3 & $\begin{array}{l}2.26,3 \\
\pm 0,26\end{array}$ & $\begin{array}{l}2.12,5 \\
\pm 0,23\end{array}$ & $2.04,2$ \\
\hline Люпін Сан & $1.56,7$ & 8 & 2 & 25,0 & - & - & $\begin{array}{l}2.30,3 \\
\pm 0,42\end{array}$ & $\begin{array}{l}2.15,5 \\
\pm 0,67\end{array}$ & $2.05,4$ \\
\hline Монпел'є & H.B. & 14 & 8 & 57,1 & 3 & 21,4 & $\begin{array}{l}2.20,0 \\
\pm 0,16\end{array}$ & $\begin{array}{l}2.09,1 \\
\pm 0,11\end{array}$ & $\begin{array}{l}2.06,9 \\
\pm 0,17\end{array}$ \\
\hline Пассворд & $1.59,3$ & 1 & 1 & 100,0 & 1 & 100,0 & - & $2.14,4$ & $2.04,5$ \\
\hline
\end{tabular}

Найбільшу кількість молодняку випробувано на іподромі від жеребців Монпел'є, Карп Д'єм, Люпін Сан (14, 9 і 8 голів, відповідно). 3 усього випробуваного потомства найбільшу частку коней класу жвавості 2.10 хв.с одержано від жеребців: Б'єсоло, Ідало та Монпел'є (по 57,1%). Молодняк класу жвавості 2.05 хв.с і жвавіше одержано лише від жеребців Монпел'є (21,4%), Інтерпід д’Авіль (14,3 \%), Карп Д'єм $(11,1 \%)$ та єдиний випробуваний потомок Пассворда.

Найвищу жвавість на дистанцію 1600 м проявило 2річне потомство жеребців: Ідало (2.18,8 $\pm 0,20$ хв.с), Еліо Жосселін (2.19,8 хв.с), Монпел'є (2.20,0 0 0,16 хв.с). У 3річному віці найвищий рівень жвавості проявило потомство

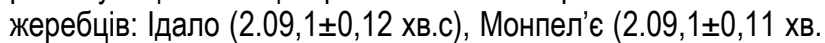
c) та Еліо Жосселін (2.10,4 хв.с). У 4-річному віці найвищий рівень жвавості проявило потомство жеребців: Інтерпід д'Авіль (2.04,2 хв.с), Пассворд (2.04,5 хв.с) та Люпін Сан (2.05,4 хв.C).

Коні, одержані від жеребців фрранцузької рисистої породи в середньому виявилися жвавішими за ровесників, одержаних від жеребців американської стандартбредної породи (табл. 6): у віці двох років - на 0,5 с, трьох років - на 1,2 с, чотирьох років - на 1,1 с. При цьому у потомстві жеребців американської стандартбредної породи виявлено більше коней класу жвавості 2.10 хв. с і жвавіше - на 7,2 \%, класу жвавості 2.05 хв.с і жвавіше - на 8,9\%. Жеребціплідники американської стандартбредної породи в середньому поступалися жеребцям французької селекції за жвавістю на 1600 м на 2,3 с.

Таблиця 6

Порівняльний аналіз ефективності використання плідників французької рисистої та американської стандартбредної породи, допущених до схрещування з російською рисистою породою вітчизняної селекції (2006-2016 рр.)

\begin{tabular}{|c|c|c|c|c|c|c|c|c|c|c|}
\hline \multirow{3}{*}{ Порода жеребця-плідника } & \multirow{3}{*}{$\begin{array}{c}\text { Кількість } \\
\text { жеребців, } \\
\text { гол. }\end{array}$} & \multirow{3}{*}{$\begin{array}{c}\text { Жвавість, } \\
\text { на } 1600 \text { м, } \\
\text { хв.с }\end{array}$} & \multirow{3}{*}{$\begin{array}{c}\text { Випробувано } \\
\text { потомства, } \\
\text { гол. }\end{array}$} & \multicolumn{4}{|c|}{ Виявлено коней класу жвавості, хв.с: } & \multicolumn{3}{|c|}{$\begin{array}{c}\text { Жвавість на дистанцію } 1600 \text { м у } \\
\text { вікові періоди, років: }\end{array}$} \\
\hline & & & & \multicolumn{2}{|c|}{2.10} & \multicolumn{2}{|c|}{2.05} & \multirow{2}{*}{2} & \multirow{2}{*}{3} & \multirow{2}{*}{4} \\
\hline & & & & $\mathrm{n}$ & $\%$ & $\mathrm{n}$ & $\%$ & & & \\
\hline Французька рисиста & 12 & $\begin{array}{l}1.58,5 \\
\pm 0,05\end{array}$ & 60 & 26 & 43,3 & 5 & 8,3 & $\begin{array}{l}2.25,5 \\
\pm 0,12\end{array}$ & $\begin{array}{l}2.12,2 \\
\pm 0,08\end{array}$ & $\begin{array}{l}2.07,4 \\
\pm 0,07\end{array}$ \\
\hline $\begin{array}{l}\text { Американська } \\
\text { стандартбредна }\end{array}$ & 16 & $\begin{array}{l}2.00,8 \\
\pm 1,39\end{array}$ & 93 & 47 & 50,5 & 16 & 17,2 & $\begin{array}{l}2.26,0 \\
\pm 0,80\end{array}$ & $\begin{array}{l}2.13,4 \\
\pm 0,81\end{array}$ & $\begin{array}{l}2.08,5 \\
\pm 0,62\end{array}$ \\
\hline
\end{tabular}

Таким чином встановлено, що використання генофонду французької рисистої породи для схрещування дає можливість поліпшити селекційні ознаки коней російської рисистої породи вітчизняної популяції і зменшити інбредну депресію в умовах роботи з обмеженим генофондом породи.

Висновки. 1. Використання генофонду французької рисистої породи для схрещування дає можливість поліпшити селекційні ознаки коней російської рисистої породи вітчизняної популяції і зменшити інбредну депресію в умо- вах роботи з обмеженим генофондом породи.

2. Експериментально доведено позитивний вплив схрещування російської рисистої породи 3 французькою рисистою на удосконалення характеристик жвавості коней. В усіх вивчених групах молодняк, помісний за французькою рисистою породою переважав чистопородних ровесників обох рисистих порід за жвавістю на 1600 м. Коні, одержані від жеребців французької рисистої породи виявилися жвавішими за ровесників, одержаних від жеребців американської стандартбредної породи: у віці двох років - на 0,5 c,

Вісник Сумського національного аграрного університету 
трьох років - на 1,2 с, чотирьох років - на 1,1 с. При цьому у потомстві жеребців американської стандартбредної породи виявлено більше коней класу жвавості 2.10 хв. с і жвавіше на 7,2 \%, класу жвавості 2.05 хв.с і жвавіше - на 8,9\%.
Жеребці-плідники американської стандартбредної породи в середньому поступалися жеребцям французької селекції за жвавістю на 1600 м на 2,3 с.

\section{Список використаної літератури:}

1. Olsen H.F., Klemetsdal G. Clustering the relationship matrix as a supportive tool to maintain genetic diversity in the Scandinavian cold-blooded trotter. Acta Agriculturae Scandinavica. 2018. Vol. 68. Published online: doi.org/10.1080/09064702.2018.1542452

2. Корнієнко О.О., Волков Д.А., Ткачова І.В., Гданська К.В., Алещенко О.О. Порівняльна характеристика селекційних ознак популяції коней російської рисистої породи України та Російської Федерації як передумова для відокремлення та формування українського внутрішньопородного типу. Науково-технічний бюлетень Інституту тваринництва НАAН. 2014. № 111. C.84-95.

3. Калашников В.В. Селекционно-генетические методы в коннозаводстве. Достижения науки и техники АПК. 2009. № 7. C.46-49

4. Ткачова І.В., Ткаченко О.О., Марущак В.Д., Радченко М.В., Гавриленко М.Д., Лабунець А.С., Гніда О.О., Гнідий О.В., Ломакін В.Г., Присяжнюк І.Л., Дубовик В.І. Українська рисиста породна група коней. Аграрна наука - виробництву. Київ, «Аграрна наука», 2017. № 3 (81). С.21.

5. Канакова Н.Б. Сравнительная характеристика лошадей рысистых пород по экстерьеру и резвости. Вестник Ульяновской государственной сельскохозяйственной академии. 2018. Вип. 4 (20). С.92-94.

6. Корнієнко О.О. Оцінка стану рисистого кіннозаводства України. Науково-технічний бюлетень IT НААН. Харків, 2012. № 106. C.54-59.

7. Thiruvenkadan A.K., Kandasamy N., Panneerselvam S. Inheritance of racing performance of trotter horses: an overview. Livestock Science. 2009. Vol. 124. № 1-3. 163-181. doi.org/10.1016/j.livsci.2009.01.010

8. Иванова И.П., Троценко И.В. Продуктивные качества кобыл русской рысистой породы в зависимости от генотипа. Вестник Красноярского государственного аграрного университета. 2017. № 2. C.54-59.

9. Калашников О.В. Нужны французские рысаки. Коневодство и конный спорт. 1988. № 5. С.13.

10. Липпинг В.О. Новые производители, импортированные из Франции. Коневодство и конный спорт. 1965. № 2. C.19-21

11. Витт В.О. О французских рысаках. Французские рысаки: приложение к бюлетеню «Беговые ведомости». Москва, Ассоциация «Содружество». 2002. Вып.1. С.5-13

12. Bohlin O., Ronningen K. Inbreeding and Relationship within the Nort-Swedish Horse. Acta Agriculturae Scandinavica. 1975. Vol. 25. P.121-125. doi.org/10.1080/00015127509436242

13. Ткачова І.В. Використання плідників фрранцузької рисистої породи при удосконаленні вітчизняної частини популяції російської рисистої породи коней. Тваринництво України. 2007. № 10. С.24-28.

14. Калашников В. В., Фомин А. Б. Резвость русско-французских помесей. Коневодство и конньй спорт. 1975. № 4. C. $12-13$.

15. Хлопцева Л. С. Минден и его потомство. Беговые ведомости. 2001. № 3 (33). С.34-35.

16. McCoy A.M., Beeson S.K., Rubin C.-J., Andersson L., Caputo P., Lykkjen S., Moore A., Piercy R.J., Mickelson J.R., McCue M.E. Identification and validation of genetic variants predictive of gait in standardbred horses. Public Library of Science. 2019. Vol. 15; doi.org/10.1371/journal.pgen.1008146

17. Kennedy B.W., Quinton M., van Arendonk J.A. Estimation of effects of single genes on quantitative traits. Journal of Animal Science. Vol. 70. № 7. 1992. P.2000-2012. doi.org/10.2527/1992.7072000x

\section{References:}

1. Olsen H.F., Klemetsdal G. (2018). Clustering the relationship matrix as a supportive tool to maintain genetic diversity in the Scandinavian cold-blooded trotter. Acta Agriculturae Scandinavica. Vol. 68. doi.org/10.1080/09064702.2018.1542452

2. Kornienko. O.O., Volkov. D.A., Tkachova. I.V., Gdans'ka. K.V., and Aleshchenko. O.O., 2014. Porivnyal'na harakteristika selekcijnih oznak populyaciï konej rosijs'koï risistoï porodi Ukraïni ta Rosijs'koï Federaciï yak peredumova dlya vidokremlennya ta formuvannya ukraïns'kogo vnutrishn'oporodnogo tipu [Comparative characterization of breeding traits of horses of the Russian lynx of Ukraine and the Russian Federation as a prerequisite for separation and formation of the Ukrainian domestic breed. Scientific and Technical Bulletin of the Institute of Animal Breeding of the NAAS]. Scientific and Technical Bulletin of the Institute of Animal Breeding of the NAAS. issue 111, pp. 84-95.

3.Kalashnikov. V.V., 2009. Selekczionno-geneticheskie metody` v konnozavodstve. [Breeding and genetic methods in horse breeding]. Dostizheniya nauki i tekhniki APK. № 7. pp. 46-49.

4.Tkachova. I.V., Tkachenko. O.O., Marushchak. V.D., Radchenko. M.V., Gavrilenko. M.D., Labunetc. A.S., Gnida. O.O., Gnidij. O.V., Lomakin. V.G., Prisyazhnyuk. I.L. and Dubovik. V.I., 2017. Ukrains'ka risista porodna grupa konej. [Ukrainian Trotting group of horses]. Agrarna nauka - virobnictvu. Kiïv, «Agrarna nauka». № 3 (81). p. 21.

5. Kanakova. N.B., 2018. Sravnitel'naya harakteristika loshadej rysistyh porod po ekster'eru i rezvosti [Comparative characteristics of trotter breed horses by exterior and agility]. Vestnik Ul'yanovskoj gosudarstvennoj sel'skohozyajstvennoj akademii. issue 4 (20). pp. 92-94.

6. Kornienko. O.O., 2012. Ocinka stanu risistogo kinnozavodstva Ukraïni [Assessment of the state of trotting equestrian 
production in Ukraine]. Scientific and Technical Bulletin of the Institute of Animal Breeding of the NAAS. issue 106. pp. 54-59.

7. Thiruvenkadan. A.K., Kandasamy. N., Panneerselvam. S., 2009. Inheritance of racing performance of trotter horses: an overview. [Productive qualities of mares of the Russian trotter breed depending on the genotype]. Livestock Science. issue 124. № 1-3. pp. 163-181. doi.org/10.1016/.j.ivsci.2009.01.010

8. Ivanova. I.P., Trocenko. I.V., 2017. Produktivnye kachestva kobyl russkoj rysistoj porody v zavisimosti ot genotipa [Productive qualities of mares of the Russian trotter breed depending on the genotype]. Vestnik Krasnoyarskogo gosudarstvennogo agrarnogo universiteta. № 2. pp. 54-59.

9. Kalashnikov. O.B., 1988. Nuzhny francuzskie rysaki [Need a French trotter]. Konevodstvo i konnyj sport. № 5. p. 13.

10. Lipping. V.O., 1965. Novye proizvoditeli, importirovannye iz Francii [New manufacturers imported from France] . Konevodstvo $i$ konnyj sport. № 2. pp. 19-21.

11. Vitt. V.O., 2002. O francuzskih rysakah [About the French trotters]. Francuzskie rysaki: prilozhenie $k$ byuletenyu «Begovye vedomosti». Moskva, Associaciya «Sodruzhestvo». issue 1. pp. 5-13.

12. Bohlin. O., Ronningen. K., 1975. Inbreeding and Relationship within the Nort-Swedish Horse. Acta Agriculturae Scandinavica. Vol. 25. pp. 121-125. doi.org/10.1080/00015127509436242

13. Tkachova. I.V. 2007. Vikoristannya plidnikiv francuz'koyi risistoyi porodi pri udoskonalenni vitchiznyanoï chastini populyaciï rosijs'koyi risistoyi porodi konej [The use of French trotter breeders in improving the domestic part of the Russian trotter breed population]. Tvarinnictvo Ukraïni. № 10. pp. 24-28.

14. Kalashnikov. V.V., Fomin. A.B., 1975. Rezvost' russko-francuzskih pomesej [The harshness of Russian-French crosses]. Konevodstvo i konnyj sport. № 4. pp. 12-13.

15. Hlopceva. L.S., 2001. Minden i ego potomstvo. Begovye vedomosti. № 3 (33). pp. 34-35.

16. McCoy. A.M., Beeson. S.K., Rubin. C.-J., Andersson. L., Caputo. P., Lykkjen. S., Moore. A., Piercy. R.J., Mickelson. J.R. and McCue. M.E., 2019. Identification and validation of genetic variants predictive of gait in standardbred horses. Public Library of Science. Vol. 15; doi.org/10.1371/journal.pgen.1008146

17. Kennedy. B.W., Quinton. M., van Arendonk. J.A. (1992). Estimation of effects of single genes on quantitative traits. Journal of Animal Science. Vol. 70. № 7. pp. 2000-2012. doi.org/10.2527/1992.7072000x

Tkachova, I.V.,

Tkachenko, 0.0 .

Efficiency of crossing the Russian Trotter breed of the Ukrainian population with the French Trotter breed

To improve the Russian Trotter breed of Ukrainian and Russian populations, crossing with the original American standardbred is traditionally used, which comes from a thoroughbred horse and is the most popular of all trotting breeds. An alternative to absorbing crossbreeding of trotting horses of Ukrainian selection with the American standardbred is the moderate use of French Trotter breed producers, which over the past decade has been gaining in selection on an increasing scale. The popularity of French Trotter breed producers in Ukrainian breeders in recent years is associated with their success on world racetracks, as well as due to their origin from the outstanding producers of the American standardbred breed and belonging to progressive lines and branches. Thus, using them, breeders compensate for the lack of high-class producers of American standardbred breeds. It was found that using the French Trotter breed gene pool for crossbreeding makes it possible to improve the breeding characteristics of horses of the Russian Trotter breed in the Ukrainian population and reduce inbreeding depression in conditions of selection with a limited breed gene pool. The positive effect of crossing the Russian Trotter breed with the French Trotter on improving the characteristics of the horse's agility was experimentally proved. In all the groups studied, the young, French Trotter was superior to purebred peers of both trotting breeds in speed at $1600 \mathrm{~m}$. Horses, stallions obtained from the French Trotter breed was very much the same age, obtained from the American standardbred stallions of the breed: at the age of two years old $0.5 \mathrm{~s}$, three years old, $1.2 \mathrm{~s}$, four years old $1.1 \mathrm{~s}$. in the offspring of standardbred stallions of the American breed more horses discovered class of liveliness 2.10 min and alive - 7.2 $\%$, grade of $2.05 \mathrm{~min}$. with liveliness and alive - by $8.9 \%$. Stallions of the American standardbred breed on average were inferior to stallions of the French selection in speed at $1600 \mathrm{~m}$ by $2.3 \mathrm{~s}$.

Key words: horses, Ukrainian population, Russian Trotter, French Trotter, crossing, speed

Дата надходження до редакції: 10.02.2019 p. 